Research Report No. 33/2008

\title{
Comparative Regulatory Regimes in Water Service Delivery: Emerging Contours of Global Water Welfarism?
}

Bronwen Morgan

Follow this and additional works at: http:/ / digitalcommons.osgoode.yorku.ca/clpe

\section{Recommended Citation}

Morgan, Bronwen, "Comparative Regulatory Regimes in Water Service Delivery: Emerging Contours of Global Water Welfarism?" (2008). Comparative Research in Law \& Political Economy. Research Paper No. 33/2008.

http://digitalcommons.osgoode.yorku.ca/clpe/204 


\section{Comparative Research in Law \& Political Economy}

\section{Bronwen Morgan}

Comparative Regulatory Regimes in Water Service Delivery: Emerging Contours of Global Water Welfarism?

EDTORS: Peer Zumbansen (Osgoode Hall Law School, Toronto, Director, Comparative Research in Law and Political Economy, York University), J ohn W. Cioffi (University of California at Riverside), Lindsay Krauss (Osgoode Hall Law School, Toronto, Production Editor) 

CLPE Research Paper 33/2008

Vol. 04 No. 07 (2008)

\title{
Bronwen Morgan
}

\section{Comparative REgulatory Regimes in WATER SERVicE DELIVERY: EMERGING CONTOURS OF GLOBAL WATER WELFARISM?}

\begin{abstract}
This paper explores one particular dimension of broader global policy issues concerning water resources: the regulatory governance aspect of delivering water services to ordinary citizens in urban contexts for domestic use. Water provision, as with many other areas of collective provision, is increasingly shaped by attempts to embed social facets into the expansion of transnational markets: part of the incremental growth of 'globalisation with a human face'. The paper first summarises nascent transnational institutional developments in policymaking and provision around urban water services delivery. It stresses that this process is still heavily dependent on national and local state institutions, particularly domestic regulatory institutions.
\end{abstract}

The paper then elaborates a theoretical framework frames empirical findings from case studies of the regulatory governance of water services in Bolivia, Chile and Argentina during the 1990s and early 2000s. These case studies illustrate how transnational dynamics create a regulatory intersection of social policy and global governance. This pattern could be emblematic of potential trajectories of transnational regulatory politics in areas beyond water (most obviously other public utilities such as gas and electricity, but also health and education).

Keywords: water, globalization, globalisation, regulation, Bolivia, Chile, Argentina

JEL classification: I38, K23, K33 


\section{Author Contact:}

\section{Bronwen Morgan}

University of Bristol, United Kingdom

Email: B.Morgan@bristol.ac.uk 


\title{
COMPARATIVE REgUlatory REgIMES IN WATER SERVICE DELIVERY: EMERGING CONTOURS OF GLOBAL WATER WELFARISM?
}

\author{
Bronwen Morgan*
}

\section{INTRODUCTION}

The problem of scarce water resources has emerged as a global policy issue of significant prominence over the past five to ten years. In particular, access to water understood broadly has arguably become a flashpoint issue for debates over the social dimensions of globalisation. In popular discourse, this debate focuses on whether a 'human face' to globalisation can be successfully crafted at the transnational level, or whether globalisation needs to be rolled back, and distributive and equality issues can be tackled within national boundaries. This paper explores a very specific dimension of the broader question of access to water: namely, the delivery of water services to ordinary citizens in urban contexts for domestic use. Rather than focusing on water resources (irrigation, cross-border river basins, etc), it narrows its lens to the question of access to sufficient clean water for domestic human use. ${ }^{1}$ This is perhaps the most urgent 'social' question within global water policy debates, as 1.2 billion people worldwide still lack access to minimal amounts of safe drinking water, though the seventh Millenium Development Goal hopes to halve this number by 2015. Of course, the provision of access to domestic drinking water is intimately linked to the quantity and quality of water resources more broadly, which are under pressure - some would say in crisis (Davis 2007) - from rapid urbanization in developing countries, from degraded infrastructure in developed countries and from pollution in both settings. But the angle of

\footnotetext{
Professor of Sociolegal Studies, University of Bristol, UK, email B.Morgan@bristol.ac.uk
}

${ }^{1}$ The focus is also on urban rather than rural contexts, meaning that the analysis largely excludes issues pertaining to water needed for subsistence food provision. 
analysis for present purposes is upon the delivery of essential services and not on the larger ecological picture.

The key transnational actors in this particular aspect of access to water debates are i) international and regional financial institutions who fund the provision of water services on the assumption of a certain model of delivery; ii) multinational companies from the UK and France wishing to invest in foreign markets; and iii) institutions for dispute resolution, particularly international arbitration forums and potentially the World Trade Organisation under the auspices of the General Agreement on Trade and Services. In the 1990s, transnational markets for water services delivery developed, led by by British and French companies. Suez (Ondeo), Vivendi (Veolia) and Thames are the three largest water service operators globally in absolute terms as well as in terms of foreign investment. These multinational companies entered into transnational contracts with national or local authorities that, in turn, often provided for international arbitration. The most important domestic actors for the purposes of this paper are regulatory agencies and organised social groups who contribute citizen and consumer perspectives - sometimes hostile - to the institutional innovation of the agency. Both the regulatory agencies and the organised social groups have transnational epistemic communities that support their goals, but for the most part, these networks have not played a causal role in the events explored in this paper. Rather, they are networks whose transnational strength and depth are constituted by the events. This is an important facet of the findings in this paper: that transnational transformations are a product of the local and often not - or not only - an effect of external influences on a state.

This growth of a transnational dimension to water services provision particularly marked in the 1990s but still highly politically salient - has led to both resistance and routinisation. Activists' challenge to market-led capitalism is summed up in the cry of 'water is a human right, not a commodity'. In response, water provision, as with many other areas of collective provision, is increasingly shaped by attempts to embed social facets into the expansion of transnational markets: part of the incremental growth of 'globalisation with a human face'. In this way, the delivery of essential services has become an arena for struggles over distributive justice, a site for social policy just as much as for economic or industrial policy (Dubash 2005), rooted in what could be called 'the politics of 
necessity’ (Morgan and Trentmann 2006). In particular, the increasingly transnational dimensions of water services delivery and its associated policy debates mean that the politics of necessity are embedded in NorthSouth tensions typical of a range of issues in contemporary global political economy. I would suggest that the narrative of this paper is emblematic of potential trajectories of transnational regulatory politics in areas beyond water, most obviously other public utilities such as gas and electricity, but also health and education. In other words, the issue of access to water is in effect a case study that exemplifies the regulatory dimensions of a debate over whether it is possible to integrate social policy effectively into global governance.

This paper tests the expectation that similar regulatory dynamics might be expected to emerge in response to transnational influences on the domestic delivery of water services, and finds that on the contrary, national variations remain deeply embedded. This is illustrated with reference to the dynamics of domestic (national-level) regulation of access to water issues in Chile, Bolivia and Argentina in the late 1990s and early 2000s. Institutions that regulate essential services have emerged and spread widely since the 1990s (Levi-Faur) in the context of a relatively strong international mainstream consensus about their shape and purpose that I call a 'transactional' model of regulation. This consensus is embedded in strong transnational epistemic communities specialising in the technical aspects of regulation, and arguably, a noticeable imitation effect, (particularly in Latin America where the case studies explored here are all located). Against this, the strategic and cultural centrality of access to water might well lead national and local governments to focus strongly on retaining national or local control: an orientation which fits more closely with a 'political' model of regulation.

The findings of this paper indicate that in each of the three case studies, control is in fact partially ceded to semi-independent regulatory institutions that strongly resemble the institutional recommendations of the transnational consensus. But an exploration of the implementation dynamics of these institutions, focused on a time in each of conflict and disputing, reveals significant national differences. In Bolivia, the role played by the regulator in each case is coherent with the: transactional model but is politically marginalised; in Chile, a strongly transactional regulator maintains political salience, and in Argentina, a more political 
model of regulation is erratically salient. These differences can be explained by integrating political dimensions at two levels which the transactional model of regulation either sidesteps or demonises. The first level is that of contingent events at the macro-level: thus Bolivia has experienced a social and political revolution of sorts over the period studied, while Argentina has experienced an economic crisis and a divided state, and Chile remains a stable, depoliticized, investment-friendly context. At a related, but more micro, level, the political context in each country varies, particularly the strength of the social groups that contest the transactional model of regulation promoted by the dominant transnational epistemic community. These two levels interact to suggest that there are two broad competing models of global governance that shape domestic regulatory dynamics, both of which stem from a mix of local, national and transnational influences: The first, managed liberalisation, has been dominant thus far, but the second, a reinvigorated image of public provision that stresses participatory democracy rather than bureaucratic state involvement (Morgan 2006a), is gaining prominence.

Figure 1 summarises the operational roles of the regulator in each case study with particular reference to the role of transnational influences. Figure 2 summarises key aspects of the broader political context which help to explain the variation illustrated in Figure 1. The remainder of this paper will flesh out these tables in three parts. First, I outline the contours of global water welfarism and in particular the place of regulation within those contours. Second, I explore the reverberations of 'missing politics' in the three case studies of Chile, Argentina and Bolivia. Finally, the paper concludes by highlighting the implications of the case studies for our understanding of transnational transformations of the state. 
Figure 1: Operational comparison of national regulatory dynamics

\begin{tabular}{|c|c|c|c|}
\hline & Bolivia & Chile & Argentina \\
\hline $\begin{array}{l}\text { Catalyst for private } \\
\text { sector participation } \\
\text { (PSP) }\end{array}$ & $\begin{array}{l}\text { Social goals and } \\
\text { international pressure } \\
\text { (IADB) }\end{array}$ & $\begin{array}{l}\text { Economic goals and } \\
\text { international incentives } \\
\text { (WTO) }\end{array}$ & $\begin{array}{l}\text { President Menem’s } \\
\text { reforms }\end{array}$ \\
\hline $\begin{array}{l}\text { Timing and level of } \\
\text { government }\end{array}$ & $\begin{array}{l}\text { Just before PSP } \\
\text { Central }\end{array}$ & $\begin{array}{l}9 \text { years before PSP } \\
\text { Central govt }\end{array}$ & $\begin{array}{l}\text { With PSP } \\
\text { Provincial }\end{array}$ \\
\hline $\begin{array}{l}\text { Role and texture of } \\
\text { regulator }\end{array}$ & $\begin{array}{l}\text { Basic technical expertise, } \\
\text { inadequate legal } \\
\text { structure, independent }\end{array}$ & $\begin{array}{l}\text { Expert technocracy, low } \\
\text { discretion, relatively } \\
\text { independent }\end{array}$ & $\begin{array}{l}\text { Low on expertise, played } \\
\text { populist role }\end{array}$ \\
\hline $\begin{array}{l}\text { International } \\
\text { arbitration? }\end{array}$ & Yes & No & Yes \\
\hline Overall & $\begin{array}{l}\text { Some formal technical } \\
\text { capacity from a } \\
\text { transactional } \\
\text { perspective; politically } \\
\text { marginalised }\end{array}$ & $\begin{array}{l}\text { Formal and substantive } \\
\text { transactional capacity; } \\
\text { politically salient }\end{array}$ & $\begin{array}{l}\text { Politicised; salient when } \\
\text { catalysed by } \\
\text { ombudsman }\end{array}$ \\
\hline
\end{tabular}

Figure 2: Contextual comparison of national regulatory dynamics

\begin{tabular}{|c|c|c|c|}
\hline & $\begin{array}{l}\text { Bolivia (transactional } \\
\text { but marginalised) }\end{array}$ & $\begin{array}{l}\text { Chile (transactional and } \\
\text { politically salient) }\end{array}$ & $\begin{array}{l}\text { Argentina } \\
\text { (politicised but - } \\
\text { erratically - salient) }\end{array}$ \\
\hline $\begin{array}{l}\text { Key focus of broad } \\
\text { regulatory dynamics }\end{array}$ & $\begin{array}{l}\text { Legislative framework } \\
\text { for water resources } \\
\text { broadly: irrigation, } \\
\text { mining }\end{array}$ & $\begin{array}{l}\text { Procurement policies, tariff- } \\
\text { setting and accounting } \\
\text { processes, mergers }\end{array}$ & $\begin{array}{l}\text { Legislation mandating } \\
\text { social tariffs }\end{array}$ \\
\hline 'Main action' & $\begin{array}{l}\text { Popular politics and mass } \\
\text { mobilisation, legislative } \\
\text { negotiations }\end{array}$ & $\begin{array}{l}\text { Legalised power struggles } \\
\text { between major interests; } \\
\text { limited, ineffective party } \\
\text { politics }\end{array}$ & $\begin{array}{l}\text { Mix of party politics and } \\
\text { popular action, and small } \\
\text { claims lawsuits }\end{array}$ \\
\hline $\begin{array}{l}\text { Principal source of } \\
\text { rich data }\end{array}$ & $\begin{array}{l}\text { Deliberative and } \\
\text { participatory drafting; } \\
\text { social control of } \\
\text { company }\end{array}$ & $\begin{array}{l}\text { Regulator-company disputes } \\
\text { within regulator and in court }\end{array}$ & $\begin{array}{l}\text { Ombudsman-court- } \\
\text { regulator sequence }\end{array}$ \\
\hline $\begin{array}{l}\text { Implicit social } \\
\text { imaginary }\end{array}$ & $\begin{array}{l}\text { Politically driven local } \\
\text { development }\end{array}$ & Legalistic public interest & $\begin{array}{l}\text { 'Popcorn’ } \\
\text { incrementalism’ }\end{array}$ \\
\hline
\end{tabular}




\section{REGULATION IN THE SHADOW OF GLOBAL WATER WELFARISM}

The structure of global water policy is complex, but can be presented for present purposes as a simplified model that focuses on the regulation, provision and policymaking environment of urban water services. ${ }^{2}$ There are no formal international institutions responsible for the regulation of water services at the global level. Moreover although transnational companies are involved in the provision of water services, from a formal perspective and especially from a perspective of legal rights and obligations, water service delivery is still deeply embedded in national domestic structures and institutions. It is also important to note that in terms of volume provision is also still overwhelmingly embedded in state structures: public operators deliver 95\% of networked water services. Where access to water is limited, small-scale private independent operators (ranging from individual water vendors to low-technology neighbourhood systems) dominate. But large private corporations are increasingly involved in water services delivery, including on a crossborder basis (Leclerc \& Raes, 2001; Silva, Tynan, \& Yilmaz, 1998). An extraordinary 7,300\% increase on 1974-1990 private sector investment in water sanitation occurred between 1990 and 1997. This has since declined to an absolute level of half the 1997 peak, totalling $11 \%$ of all water and sanitation investments (Simpson, 2005:15). But the political salience of the regulatory framework for commercial deliver of water services is unlikely to be diluted. For even if the withdrawal of multinational corporations from cross-border contracts turns out to be neither partial nor temporary, it is unlikely to change the pressure coming from financial institutions that lend money to large infrastructure projects to restructure service provision along commercial lines. ${ }^{3}$

\footnotetext{
2 In a forthcoming publication (Morgan 2007), I argue that global water welfarism operates in three dimensions: fiscal, administrative and legitimation, all embedded in a tightly woven complex between Poverty Reduction Strategy Plans, Millenium Development Goals and public-private partnership structures.

3 The most recent instantiations of these heated debates have moved beyond dichotomous discussions of 'public vs private'and focus on complex ranges of mixed public-private
} 
Developments that privilege private and transnational structures are even more pronounced in relation to policymaking functions than they are in relation to provision. Both intergovernmental (Dublin Statement, 1992; European Commission, 2004; UN, 1978, 2000, 2005) and hybrid publicprivate fora have emerged as sites for debates over access to water and for the formulation of influential position papers on key issues. The most prominent hybrid forum is the tri-annual World Water Forum, hosted by the World Water Council, which is legally a French-based NGO but in practice a transnational organisation composed of a curious amalgam of business-based NGOs and large corporations. ${ }^{4}$ Each World Water Forum (the most recent was in Mexico in 2006) generates principles and policy documents for guiding water governance, emphasizing such core issues as 'full cost recovery' in a heavily iterative fashion. Though not a UNsponsored event, each World Water Forum also hosts a formal intergovernmental Ministerial Meeting. The UN has also created a Millennium Task Force on Water and Sanitation that will identify the best strategies for halving the number of people worldwide lacking access to water.

The combination of developments in policymaking and provision is creating the nascent outlines of a transnational institutional dimension to urban water services delivery. This development is deeply politically contested. Two broad models could be said to be competing: managed liberalisation on the one hand, and on the other, a reinvigorated image of public provision that stresses participatory democracy rather than bureaucratic state involvement (Morgan 2006a). Importantly, both models are influenced by a blend of local, national and transnational rules and institutions, and both stress the importance of social objectives in the context of the harsh distributional effects of globalising market forces. In other words, there is no necessary link between managed liberalisation and the increased involvement of transnational actors and institutions, nor between participatory democracy and local or national actors. In either

structures for the delivery of water services: see in particular Water Operator Partnership (WOP) initiatives.

${ }^{4}$ Members include Suez, Severn Trent, Vivendi, Mitsubishi, Evian, Electricite de France, Japan Dam Engineering Centre, Mitsubishi Heavy Industries, PriceWaterhouse Coopers, US Army Corps of Engineers. 
case, domestic regulatory institutions are a crucial part of the picture. Regulation is a core aspect of the political contestation over the different models, precisely because it is salient on both sides of the dichotomy of 'water as a human right' versus 'water as a commodity' (Morgan 2005). Thus whether state or private provision is envisaged, regulation is crucial, and it remains resolutely local or national. In the next section, I outline two approaches to regulation that are linked to the competing models of global water welfarism. Transactional regulation is coherent with the managed liberalisation model and political regulation with the participatory democracy model.

\section{A. POLITICAL AND TRANSACTIONAL REGULATION: THE DYSTOPIC SIDE OF 'IDEAL TYPES'}

The changes in the policy environment for urban water service delivery alluded to above are often presented as part of a larger process of embedding neoliberal policies in transnational settings (Goldman 2006; Conca 2006). Recent discussions of the 'neoliberal shift' (Peck and Tickell 2002) emphasise that while earlier phases may have focused on 'rolling back' the state, contemporary policy approaches are more inclined to stress 'rolling out' the state, in variously creative ways. Regulating for access to water is an example of this creative turn. Regulatory frameworks, institutionalised at national or local levels rather than global, are an increasingly important aspect of the overall structure, often but not always centred around independent regulatory agencies. As will be explored in detail in Part III, the specific empirical trajectories of regulatory dynamics in different national sites vary considerably. To frame this discussion, it is helpful to specify two 'ideal type' images of regulation, while also appreciating their dystopic mirror images. These two images are of a political conception of regulation on the one hand and - perhaps more familiar - a transactional image on the other hand. It is important not to assume that the two necessarily fall on opposite sides of the political conflicts typical of access to water. Although the emphasis on regulation which has emerged in global water policy has taken root in a broadly neoliberal context, that context has significant non-market social aspirations. These lead to an emphasis not only on the provision of stable property rights for investors but also on complementary subsidy schemes and extensive 'stakeholder' participation. Moreover, 'political' regulation 
may not necessarily benefit the poor through redistribution but may instead cement the position of local elites.

A political conception of regulation draws from the French school of 'regulationist theory' which has neo-Marxist roots, but is also compatible with a range of essentially Keynesian social welfare accounts of citizenstate relations (Klerck 1996). Here, different modes of regulation, one mode of which may be law, are envisioned as tools for balancing and ensuring a 'relatively harmonious relationship' between production, consumption and exchange in the accumulation process. Regulation in this view is importantly mediated by "historically and spatially specific institutional forms and norms of behaviour” (Klerck 1996: 111), making the contingencies of specific local contexts and the quality of social relations between producers and consumers highly salient to any analysis. In particular, the regulationist school pays specific attention to "the impact of non-commodity forms of social relations which may assist in balancing consumption and production cycles (Klerck 1996: 111).

Transactional regulation is perhaps more familiar, in content if not in name. Embedded in Weberian notions of calculability, it involves the state moving away from earlier welfare economics notions of pre-emptively correcting market failures that might harm vulnerable consumers. The state focuses instead on a more spartan role of facilitating transactional frameworks. Inside these transactional frameworks, those who implement delivery can and do address social issues, but within the purview of managerial discretion rather than as the implementation of a formal, even legal, obligation. The 'transaction' is the relationship between government and private provider, not between vulnerable consumers and a provider (public or private). Thus the quality of social relations between producers and consumers is not a direct concern for politics or law in this approach, but becomes part of market or commodity relations. Politics and law focus on the attempt to produce what one commentator vividly called 'bureaucrats with an entrepreneurial kick'!

The difference between political and transactional regulation is partly a difference of ideology and substantive belief, focused on whether allocating resources should be tied to price or to political power. It is also a different approach to the quality of rules that structure the allocation of resources. In transactional regulation, stability is paramount and thus these 
rules should be 'time-consistent'; in political regulation, rules structuring the allocation of resources are more fluid and responsive to the changing social contexts of different consumer groups. It is fair to say that on the whole, transnational actors such as multinational companies or international financial institutions promote a transactional model while national governments prefer a political model. But as we shall see in Part Two, the full story is more complex, centring on different coalitions whose members include both national and international actors.

In order to better frame the empirical complexity addressed in Part Two, it is helpful to insist upon the dystopian potential of each ideal type. To acknowledge that both political and transactional regulation can take pathological forms is to recognise, in a somewhat stylised way, the plural standpoints that necessarily characterise any collectivity. The following pictorial representation, which is drawn from a World Bank paper on regulation in Latin American water services (Foster 2005) shows, I would argue, a dystopic version of political regulation that is 'cured' by an 'ideal type' of transactional regulation. The 'reformed' model of regulation (an ideal type transactional view in my argument) seeks to eliminate 'dole handouts and partisan loans'. The vision is one of purifying clientilism: politicians become policymakers giving strategic guidance; the creation of a regulatory agency replaces political favours with a focus on technical decisions about quality and price, introduces competition, and improves cost-recovery and labour efficiency; as a consequence, the unconnected are drawn into the circle of connection.

\section{Figure 3 'Clientilist’ model of water provision}

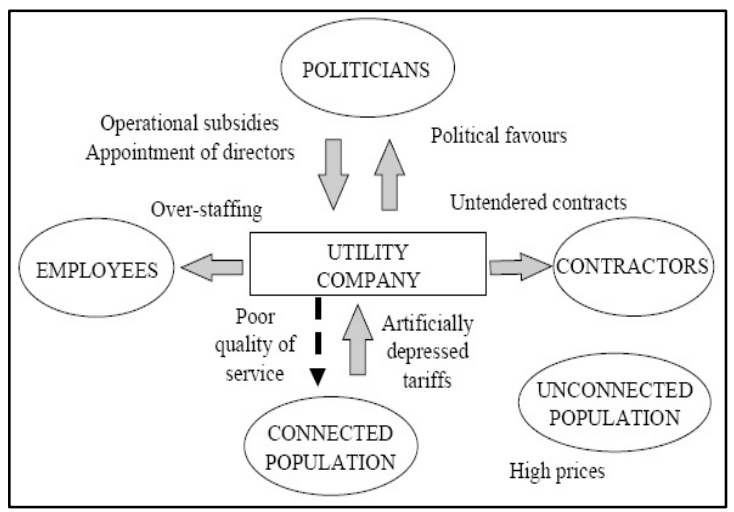


Figure 4 'Reformed' model of water provision

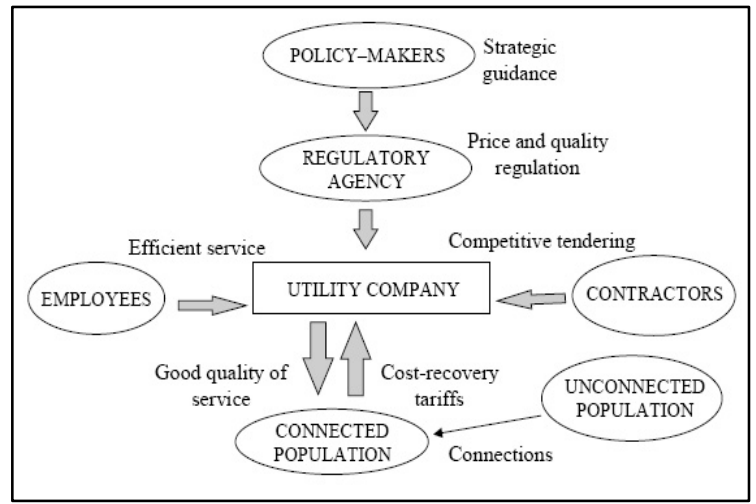

Source: Vivien Foster, 'Ten Years of Water Service Reform in Latin America: Towards an Anglo-French Model' (2005:8)

The trouble is, of course, that one person's 'dole handouts and partisan loans' may be another person's legitimate redistributive politics. Similarly, one person's view that price and quality regulation applies independent expertise to issues formerly subject to arbitrary political discretion, may be mirrored by others' opinion that this technocracy simply masks an inversely malign politics of regulatory capture. There are, in other words, 'missing' politics in the reformed model that could equally be characterised either as features of political regulation's ideal type, or as dystopic features of transactional regulation:

Figure 5:

\section{The missing politics in the 'reformed' model}

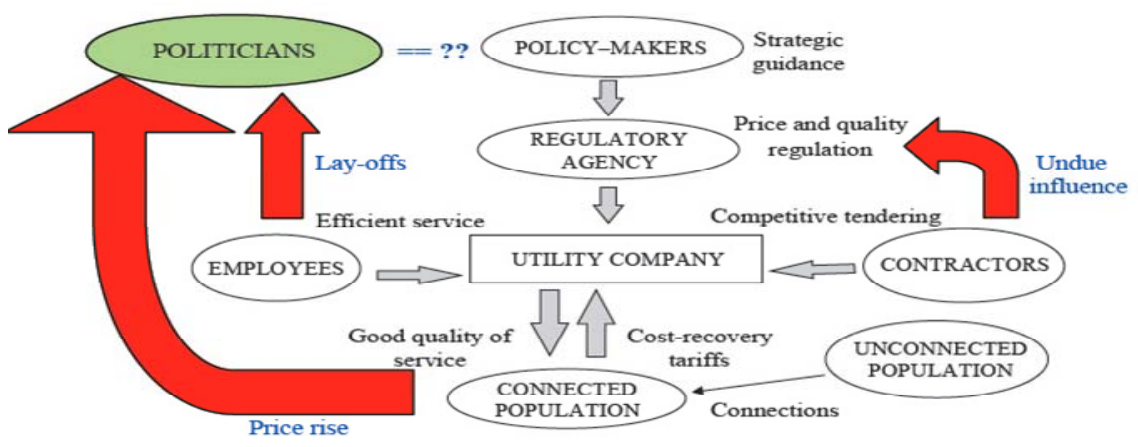


Part III will explore the ways in which these 'missing politics' shape the regulatory dynamics that emerged in Chile, Argentina and Bolivia around the delivery of water services. While they can be portrayed as indications of a clash between incompatible models of global governance, more interesting and challenging questions emerge from looking at regulatory implementation in some detail. These questions raise the possibility that transnational transformations of developing states vis-à-vis their approach to water services delivery may catalyse an integration of constructive conflict into regulatory relationships. This would involve integrating professional expertise with modulated political input and feedback in such a way that over time, a regulatory culture that blends politics and expertise is institutionalised. Such a vision builds bridges between regulatory and citizen space (Morgan 2006a), while still acknowledging the political character of regulation (Dubash 2005; Minogue 2007). Ultimately I argue that such bridges depend more crucially on local and national institutions, particularly of dispute resolution, than on transnational ones, but that productive reform can be catalysed by the transnational dimensions of regulatory change over time.

\section{COMPARATIVE REGULATORY DYNAMICS AND THE REVERBERATIONS OF 'Missing Politics'}

Part III explores the regulatory dynamics that emerged in relation to the delivery of water services in urban contexts in three Latin American case studies in Bolivia, Chile and Argentina in the late 1990s and early 2000s. ${ }^{5}$ All three countries also experienced extensive foreign investment from the world's largest water multinationals during the 1990s. Of the four largest water services firms active in the transnational water services market,

\footnotetext{
${ }^{5}$ The empirical work reported in this section is drawn from a larger project in which six qualitative comparative case studies of (in most cases) specific disputes were carried out in Argentina, Bolivia, Chile, France, New Zealand and South Africa, as well as interviews with international actors, and observations over two years of multi-stakeholder fora and trade and investment negotiations. The project aimed to explore the relationship between the local, national and transnational aspects of regulatory governance and grassroots advocacy in relation to urban water services policy. I am grateful to the UK Economic and Social Research Council for funding the research under the title 'The Commodification of Water, Social Protest and Cosmopolitan Citizenship': RES-143-250031.
} 
three are headquartered in France (Ondeo, Veolia and Saur) and one in the UK (Thames Water). The two largest, Ondeo and Veolia may be more commonly known as Suez and Vivendi. ${ }^{6}$ Suez, Vivendi and Thames all invested significantly in Chile, Bolivia and Argentina during the 1990s. ${ }^{7}$ The fieldwork on which the research is based was structured around major disputes involving transnational water companies, using Chile as a control case since it lacked a single major dispute. All three countries established regulatory agencies: Argentina at provincial level and Bolivia and Chile at central government level. In Bolivia and Argentina, the disputes studied ended with the transnational investor terminating the concession and lodging a dispute in an international arbitration forum.

The three countries share a formal similarity in their common adoption of semi-independent regulatory agencies in the water sector. However, this adoption occurred under very different contextual conditions: Bolivia was experiencing developments that led eventually to a social and political revolution of sorts with the election of Evo Morales as president; Argentina experienced a serious economic crisis in 2000; and Chile has remained a stable, depoliticized, investment-friendly context during the period studied. Their shared experience of transnational investment in cross-border markets for the delivery of water services generated a common pressure for transactional regulation, at least partially satisfied at the formal level by the existence of agencies in each country. But the detail of implementation indicates significant national variation in outcome, as the bulk of this section will explore.

Before turning to the detailed case studies, it is worth noting that the regulatory structures for water service provision in the UK and France, the

${ }^{6}$ The two largest by some margin are Ondeo (previously Suez and before that Lyonnaise des Eaux) which serves 110 million people in more than 100 countries, and Veolia (previously Vivendi Environnement and before that Compagnie Generale des Eaux) which serves 96.5 million people in 90 countries: see Gleick et al., The New Economy of Water (2002) at 24-25. Thames Water serves 22 million people: see D.Yaron, The Final Frontier (2000).

${ }^{7}$ Suez bought the regional water company providing water to Santiago, Chile and secured longterm concessions in Buenos Aires, Santa Fe and Cordoba, Argentina and La Paz, Bolivia. Thames bought initially one and eventually three regional water companies in the south of Chile. Vivendi had a stake in the Buenos Aires concession and also secured a longterm concession in the province of Tucuman, Argentina. The companies have now disinvested in all but 
home states of investor companies, usefully illustrate the contingency of transactional and political models of regulation. The UK has arguably established one of the clearest instances of transactional regulation in water services anywhere in the world, with its fully privatised water industry regulated by an independent, highly technocratic regulatory agency Ofwat. France, by marked contrast, has self-consciously chosen not to establish such an agency, rejecting this option in a high-profile legislative debate as recently as $1999 .{ }^{8}$ Rather, France has achieved public service goals in water service delivery not by state provision ${ }^{9}$ but by political regulation, ${ }^{10}$ focused initially on substantive but increasingly on procedural aspects of long-term contracting-out for private sector provision.

Such variation in the home investor country approaches is replicated even within countries. For while France has preserved political regulation internally for the provision of water services, its companies seek transactional regulation externally for the governance of their transnational investments. During the 1990s the transnational investment portfolios of French water companies increased significantly. Over the same period, France has been actively involved in trying to secure progress in transnational regulatory structures for water services. French companies and organisations were founding members of a voluntary self-regulatory regime through the International Standards Organisation (Morgan 2006c), and have lobbied vigorously to include water services in the GATS treaties. French companies also chose Latin America as their primary

\footnotetext{
${ }^{8}$ See the 1999 report of the High Council on Public Services, Quelle régulation pour l'eau et les services publics FRANCE. Haut conseil du secteur public, Paris 1999. http://www.ladocumentationfrancaise.fr/rapports-publics/004000299/ext.shtml. The proposal was highly politically sensitive and was abandoned in favour of a toothless 'water observatory' with little funding or powers: interview with M. Sironneau and M. Riveau, Department of the Environment, September 2004.

${ }^{9}$ Interestingly, even though France is often seen as the exemplar of the European 'social model' with more enthusiasm than most for an etatist vision of 'le service public', in the specific domain of water services the role of the French state has been regulatory since the late $19^{\text {th }}$ century

${ }^{10}$ Until 1982, this centred on model contracts for leases and concessions whose terms were centrally controlled, especially in relation to prices. The decentralisation reforms of the 1980s in France led to a period of fairly unregulated contractual amendments, but the 1990s saw a return of political regulation, focused now on procedural issues such as transparency of tendering.
} 
destination for pursuing longterm water concessions in the 1990s, a setting where more than perhaps anywhere else in the developing world, the spread of independent regulatory agencies had taken root (Jordana and Levi-Faur 2005). Finally, French water companies have extensively used the dispute resolution facilities provided by venues such as the International Centre for the Settlement of Investment Disputes (ICSID) in the World Bank (Morgan 2006c). It is the combination of the two strategies (political regulation at home and transactional regulation abroad) that coalesces in the vision of 'managed liberalisation' mentioned earlier as one of the competing models in global water governance.

As we shall see in the rest of Part III , a competing model is emerging from the regulatory dynamics in host states of transnational investment, an important counter to assumptions too often made that globalisation involves the subjection of developing countries to 'external' pressures to which they 'respond'. The most important source of this competing model, based on participatory visions of democracy, are the events that unfolded in Bolivia.

\section{A. WATER AND REgULATION IN BOLIVIA}

Although Suez had a major contract in Bolivia's capital, La Paz, the detailed dispute that was the subject of field research in the larger project underpinning this article was an earlier concession in Cochabamba held by a joint venture between Bechtel and International Water. The Cochabamba dispute has become an iconic reference point (in either positive or negative terms depending on one's perspective) in international regulatory and political dynamics around struggles over access to water. At the same time, the presence of 'repeat players' such as Suez in La Paz importantly shaped the Bolivian government's response to conflict over water service delivery in Cochabamba.

In 1997, Bolivia decided to involve the international private sector in water provision in Cochabamba, in part motivated by a very ambitious vision of water resource development for this normally very arid region, involving not only the operation of urban water services but also the construction of a major dam (the Miscuni Dam). Although there was certainly pressure from the Inter-American Development Bank to contract 
out this work to the private sector, there was also an undoubted enthusiasm on the part of local political elites for securing the financial backing of a large multinational for this project. As a result of this local-international coalition, the key political dynamics likely to disrupt the process were those at municipal level. This fitted badly with the timing and placement of the relevant regulatory agency. Bolivia had established a detailed legislative structure for utilities as a whole (gas, electricity, telecommunications and water) in 1994, with a 'super-regulator' (SIRESE) overseeing a range of sectoral regulators. ${ }^{11}$ This operated at central government level with little consultation with municipal governments. The government originally planned to establish separate regulators for water resources and for water services but the former ran into sufficient political opposition that by 1997, only detailed regulations for bringing into being a regulatory agency for water services had emerged.

More problematically, the framework of legal duties for the water services regulator, the Superintendent of Basic Sanitation (SISAB), was substantially amended just one month after Cochabamba's water services were concessioned to Bechtel in September 1999. The 1999 Ley de Servicios de Agua Potable y Alcantarillado Sanitario (Law 2029), despite its title focusing on the provision of water and waste services, in fact empowered SISAB to regulate water resources more generally (agricultural, irrigation, industrial, mining, etc.) at least until a specific body was created for this purpose. ${ }^{12}$ This gave SISAB highly controversial powers at the precise moment when its regulatory task expanded enormously with the entry of the international private sector into the Bolivian water services market.

An overall evaluation of SISAB's role in the Bolivian case study suggests that despite it possessing some formal technical capacity, it was politically marginalised. It was structured to emulate an idea of transactional

111994 Ley No. 1600, October 28, 1994 framework of all regulators (Sistema de Regulacion Sectorial - SIRESE).

${ }^{12}$ Specifically, the very last provision of law 2029 (dubbed a transitory article) says that the concessions and authorizations for the usage of hydrological resources as well as their revocation will be granted by a regulator to be created under the Framework Regulatory System of Renewable Natural Resources (SIRENARE). It adds, however, that this regulator is created such functions will be performed by SISAB. 
regulation but embedded in a broader context that supported political regulation at best, and from some quarters a far more populist and participatory politically driven vision of local development. It was located at central government level although water services had been delivered by public municipal-level entities. Although it was relatively independent from immediate political influence of any crude kind, and its employees did possess basic technical expertise, it had an inadequate legal structure and only 31 staff. Its birth and culture was also heavily shaped by international expertise and support, and continues to be heavily dependent on this for operating at all: international financial institutions staffed the initial unit that drafted the SIRESE framework and continues to support SISAB extensively with consultancies or even basic staff support. ${ }^{13}$ The InterAmerican Development Bank in 2002 actually become a member of ANESAPA, the Bolivian professional association of water companies, illustrating the deep interpenetration of the national and international sector in the Bolivian context. ${ }^{14}$

SISAB's regulatory role in supervising international contracts took place in the shadow of Bolivia's commitment to systems of international arbitration for dispute resolution through various bilateral investment treaties (BITs). Here in particular, the influence of international politics has been very powerful. For example, shortly after signing the concession, Bechtel relocated its corporate headquarters to the Netherlands, making it possible for Bechtel to take advantage of the protection afforded by the BIT between the Netherlands and Bolivia (there was no equivalent USBolivia BIT). Evidence from Argentina discussed below suggests that ICSIT-based dispute resolution undermines a political response to regulatory conflict, and may shore up a transactional response. However, in Bolivia, SISAB's position was not shored up, raising the question of why the regulator was so politically marginalized despite its technical capacity and strong international support?

\footnotetext{
${ }^{13}$ Interview with Silvia Arzabe, Planning Support Officer for SISAB, September 2004.

${ }^{14}$ Semapa: a un ano de la institucionalizacion, Semapa annual report 2002-3. ANESAPA began as a public sector trade organization in 1982, expanded to allow private and cooperative companies as members in 1997, and in 2002, expanded to include "national and international institutions, NGOs or natural persons with legal relations with the water sector": p.67.
} 
The answer lies in the restricted ambit of what social groups perceived as SISAB's legitimate jurisdiction. The key focus of broad regulatory dynamics in the Bolivian case was the legislative framework for water resources broadly speaking: provisions affecting irrigation, mining and so on. This was far broader than the infrastructural issues which the SISAB regulatory framework focused on, and even though the government formally gave broader duties to SISAB in the 1999 amendments, the lack of perceived legitimacy for this action stymied progress in the key action sites. These were popular politics and mass mobilization, together with legislative negotiations to create a new framework for governing water resources more generally. SISAB had little chance of emerging as an important player in this context, appearing as an agency bravely trying to join a field of professional expertise with which few of the politically salient local players were familiar, and manipulating the technical minutiae of a regulatory politics which did not resonate or have any history of engagement with local political dynamics.

Two examples suffice to illustrate this tension. The first occurred during the dispute: in December 1999, SISAB held a public hearing on tariffs. They required those who attended to register and to bring identification and consequently only 14 people pre-registered. In the event, it was suspended when SISAB realized it was likely to catalyse a large social mobilization: the latter was much more salient in shaping the policy trajectory on tariffs than SISAB's attempts at transparency. The second example comes from the period after the Cochabamba municipal water company was remunicipalised: since around 2002, SISAB has valiantly tried (with World Bank funding) to install a consumer education programme, focused on training neighbourhood board leaders, social groups, guilds, mothers associations, and church groups in matters of 'regulation, rights, obligations, complaints, and water care'. However, at the same time as this was occurring, the groups most capable of derailing the larger policy agenda were involved in extensive deliberative, participatory drafting of the new water resources legislative framework, ${ }^{15}$

\footnotetext{
${ }^{15}$ This evolved from a civil society-based organization, Comité de Gestión Integral del Agua en Bolivia (CGIAB) in 1998, to an Interinstitutional Water Council (CONIAG) collaboratively which had representatives from agriculture, sustainable development, economics, housing and basic services from the government, as well as 5 civil society representatives from peasants, irrigators, indigenous people, private sector and academia. By 2004 CONIAG had drafted and passed Law 2878 for the support of irrigators.
} 
and in instantiating 'social control' of the municipal company (Terhorst 2003). In their view this extensive consumer outreach programme only reached issues at the margins of what mattered most to people, at a point in time that was too late for them to shape the more structural decisions that would determine the allocation of resources and power. ${ }^{16}$ Comanagement, not consultation, was the politically salient issue, and was sidestepped by the design of SISAB's consumer awareness programme.

In short, the regulatory agency was focused on a technocratic approach to the 'minor water cycle' while the most politically salient players placed the 'major water cycle' at the centre of a highly politicized and expressive politics of struggle. The implicit social imaginary driving the politics of the Bolivian case - a vision of politically driven, locally rooted, holistic development - had little synergy with the independent regulatory agency modelled on the 'best practice' recommendations of international financial institutions. Instead, this social imaginary was at the root of a reinvigorated vision of participatory public management: a vision that aspires to replace the managed liberalization of global water welfarism. This has to some extent taken place in water. For example, after the election of Evo Morales, whose success was deeply rooted in struggles over access to natural resources, the international arbitration action arising from the Cochabamba dispute was eventually settled for the symbolic sum of 2 Bolivian pesos. And more recently, Bolivia very publicly withdrew from the International Convention on the Settlement of Investment Disputes (ICSID). We shall see in the Argentinian case study a different kind of compromise which favours the transactional regulation model to a greater degree. But what is emerging in Bolivia is not purely nationalist, but is embedded in moves on the international stage since Evo Morales became President, ${ }^{17}$ some in alliance with Cuba and Venezuela, ${ }^{18}$ that are arguably coalescing into a broader agenda that some call a Bolivarian Revolution' (Gott and Bartoli 2005). This illustrates that the 'politics of necessity' have their sources as much in the developing world as in the

\footnotetext{
${ }^{16}$ Crespo Carlos Crespo Flores, Oxford Brookes University, "Superintendencias: Nuevos Superpoderes (Democracia y Regulación en Bolivia)”, paper on file with author.

${ }^{17} \mathrm{Eg}$ the withdrawal from the ISCID Convention, the appointment of one of the major El Alto water activists in La Paz to the post of Water Minister.

${ }^{18}$ Eg the dissenting Ministerial Declaration at the $4^{\text {th }}$ World Water Forum in Mexico in 2006, drafted by Bolivia and endorsed by Cuba and Venezuela.
} 
industrialised world, even when the relations between them are as sharply polarised as the Bolivian case study indicates.

\section{B. WATER AND REgULATION IN CHILE}

Chile's regulatory institutions represent something much closer to the 'ideal' transactional vision supported by international financial institutions and a strong epistemic community. A number of features make Chile's politics of water privatization unique. First, access to water in Chile is far more widespread than other developing countries. In 1930, the Chilean central government made the provision of water and sewage services (WSS) a developmental priority, and unusually high coverage has subsisted especially since the 1970 s. $^{19}$ Secondly, the provision of water services is unusually centralised - even a restructuring along regional lines in the 1970s followed technocratic lines, creating 12 centrally controlled regional public companies rather than decentralising any authority to more local political levels of government. In the 1980s, the decentralization sweeping the rest of Latin America was rejected in Chile, influenced by the 'Chicago boys': economic technocrats holding powerful positions in government, many of whom were educated at the University of Chicago economics department. They argued that there was insufficient professional capacity at local government levels, and that the private sector would provide more reliable expertise as well as efficiency gains. Thirdly, Chile is unusually urban - only $10 \%$ of the population lives in rural areas. And finally, there is a relatively low level of civil society activism, particularly around issues of socio-economic policy. ${ }^{20}$

Thus rather than an urgent need for investment for basic access to water, the catalyst for the entry of the international private sector into Chile's WSS sector was two-fold in the 1980s: ideological neo-liberalism, and the need to raise private finance to build waste treatment plants. Some argue

${ }^{19}$ Coverage is $99.7 \%$ and 24 hours a day and sewage is 94\%: Alexander Chechilnitzky, “AIDIS: 55 anos de fructifera labor”, La Revista de Aidis-Chile, September 2003.

${ }^{20}$ The causes of this are not clear - many interviewees attributed it to Chilean culture, but the lingering effects of Pinochet's dictatorship may be just as material: see Houtzager and Kurtz 2000 for an argument about the lingering effects of institutional and structural changes introduced by Pinochet on rural grass-roots mobilization. See also Foweraker 2001. 
that the US-Chile free trade agreement created legal pressures to meet international standards in wastewater treatment in order to facilitate fruit exports - but it is not entirely clear if this was a post hoc justification for an otherwise ideological decision to involve the private sector. It does appear, however, that economic export-oriented goals were an important part of the motivation, and the percentage of wastewater that is now treated has almost doubled between 1998 and $2005 .^{21}$

Chile's water services have undergone three main reforms in the structure of provision: corporatisation 1989-1998 (associated with efficiency gains), a brief period of privatisation 1998-2001 (associated with raising capital to build waste treatment plants) and concessioning 2001-present (associated with a political backlash against privatization). The public water companies were restructured along 'corporatised' lines in 1989 just before democracy returned to Chile, ${ }^{22}$ and Aylwin's centre-left government left this in place. Almost a decade later, after a stormy debate in 1998 under the centre-left government of Eduardo Frei, legislation to allow privatization was passed, albeit with a ceiling on ownership. ${ }^{23}$ This ceiling was quietly removed a few months later in a little-noticed tax bill. ${ }^{24}$ Between 1998 and 2000, five of the 13 regional companies were privatised. $^{25}$ The remaining eight were offered out to long-term concessions rather than outright privatisation. ${ }^{26}$ Few seem to think that the difference between outright asset sales and long-term concession has any powerful political or even practical implications. Indeed, despite the shift away from privatisation towards the concession system, another littlenoticed tax bill in 2003 allowed four of the five companies originally

\footnotetext{
${ }^{21}$ Treated wastewater levels were $42 \%$ in 2003 but were on target to reach $81 \%$ by the end of 2005: Alexander Chechilnitzky, “AIDIS: 55 anos de fructifera labor”, La Revista de Aidis-Chile, September 2003.

${ }^{22}$ The state industry development arm CORFO was relieved of service delivery obligations in water. 13 regional joint-stock companies were created: Ley 18.777 of 17 January 1989

${ }^{23}$ General Law for Sanitation Services (Law 19,549, 1995 bill) of February 51998.

${ }^{24}$ Article 5 of Ley 19,888 of 14 July 1998 (a general tax law) abolished any ceiling on the sale of shares in water companies.

${ }^{25}$ Emos (Santiago - Suez), Esval (Valparaiso, Region V - Anglian), Essbio (Concepion, Region VIII - Thames), Essel (Region VI - Thames) and Essal (Region VIII - Iberdrola).

${ }^{26}$ An internal review by the then President Richard Lagos in the late 1990s, then Minister of Public Works (and later to be President in 2001) underpinned this policy shift.
} 
privatised in the late 1990 s to be sold entirely. ${ }^{27}$ This narrative encapsulates Chilean regulatory dynamics in the water sector: an odd mix of polarised public political debate that fails to alter the direction of the policy trajectory, together with major decisions made in the interstices of technical and obscure legislation.

Water services in Chile are regulated by SISS (the Superintendency of Sanitation Services). ${ }^{28}$ SISS is a regulatory agency that replaced a government department in 1990 when corporatisation took place. Consistent with transactional models of regulation, the key relationships were those between the regulator and the regional companies, rather than those with consumers. During the 1990s, these relationships (between SISS and the regional companies) were ones of negotiation and fairly cordial bargaining. The shift to privatisation in 1998 inaugurated a more adversarial relationship between operators and regulator. In the wake of the rapid privatisation of 5 of the 13 companies, between 2000 and 2001 fines imposed by SISS increased by $69 \% .^{29}$. An analysis of SISS data on adjudicatory decisions by the regulator together with judicial appeals (1995-2005: see Figure 1) shows that the privatised companies dominate the statistics of above-average fines levied, the highest rates of large fines, and the highest appeal rates against fines. ${ }^{30}$ The actions were also almost without exception initiated by the regulator or the company rather than consumers, and focused mainly on defining the limits of property rights as between regulator and operator - i.e. typical of transactional regulatory politics. Moreover, although SISS usually prevailed upon appeal, and although at least some of these instances should have indirectly benefited

\footnotetext{
${ }^{27}$ A bill to "establish the funding needed to ensure the priority social objectives of the government":Ley 19888 of August 2003, Article 5. Emos, the Santiago company and the most politically sensitive, was not included.

${ }^{28}$ Chile's water resources are regulated by the general water department (DGA), a unit of the Ministry of Public Works which oversees a complex system of tradeable water rights established in 1981 (a system beyond the scope of this research).

${ }^{29}$ Morrison Foerseter, Quarterly Report on Water Industry Developments in Latin America March 2002. 2001 fines were 33 in number totalling US\$1.07 million

${ }^{30}$ One interesting exception to the general pattern is Essbio, the Thames-owned company which attracted the highest fines but did not feature in the high appeal statistics. This can be explained by the fact that Essbio attracted more political controversy than any other water company in Chile and may have considered the political costs of appealing greater than the likelihood of success.
} 
consumers, the Chilean water sector lacks any legal device for indemnifying consumers.

Figure 4: Analysis of cases brought to Chilean water regulator SISS 1995-2005

\begin{tabular}{|c|c|c|c|c|c|c|}
\hline Company & No of fines & $\%$ of total & Appealed or not & $\begin{array}{c}\% \\
\text { appealed }\end{array}$ & $\begin{array}{c}\text { Fines } \\
=\text { or }> \\
300 \\
\text { UTM }\end{array}$ & $\begin{array}{c}\text { Average } \\
\text { fine }\end{array}$ \\
\hline Aguas Andinas & 3 & $2 \%$ & 3 & $100 \%$ & 0 & 200 \\
\hline Essar & 5 & $3 \%$ & 0 & $0 \%$ & 0 & 9 \\
\hline Esmag & 2 & $1 \%$ & 0 & $0 \%$ & 0 & 55.5 \\
\hline Essan & 3 & $2 \%$ & 0 & $0 \%$ & 0 & 85.67 \\
\hline Essel & 23 & $16 \%$ & 2 & $9 \%$ & 10 & 243.43 \\
\hline Essam & 10 & $7 \%$ & 1 & $10 \%$ & 1 & 259.8 \\
\hline Essat & 12 & $8 \%$ & 2 & $17 \%$ & 2 & 260.33 \\
\hline Essbio & 23 & $16 \%$ & 5 & $22 \%$ & 8 & 488.91 \\
\hline Essco & 7 & $5 \%$ & 2 & $29 \%$ & 2 & 137.14 \\
\hline Emmssa & 3 & $2 \%$ & 1 & $33 \%$ & 0 & 48.67 \\
\hline Essal & 13 & $9 \%$ & 6 & $46 \%$ & 3 & 217.15 \\
\hline Emssat & 6 & $4 \%$ & 3 & $50 \%$ & 0 & 48.33 \\
\hline Emos & 21 & $15 \%$ & 11 & $52 \%$ & 3 & 137.14 \\
\hline Esval & 13 & $9 \%$ & 8 & $62 \%$ & 5 & 446.85 \\
\hline Total & 144 & $100 \%$ & $31 \%$ & $33.10 \%$ & $23.61 \%$ & 202.92 \\
\hline
\end{tabular}

Average fine

202.92

Above average
fines
Average appeal
rate
Those with
highest appeal
rates
Highest rate of
big fines
Highest fines per
se
Big fines as \% of
total fines

Essbio, Esval, Essat, Essam, Essel, Emmssa

$31 \%$

Esval, Emos, Essal

Essbio, Essel, Esval, Essal, Essat, Emos, Essam

Essbio, Esval, Essam, Essat

Essbio+Esval+Essam+Essat=10968/total fines $36487=30.06 \%$

Source: compiled from analysis of SISS records 
Regulatory politics in Chilean water services are characteristic of broader macro-characteristics of Chile's economy, which is heavily structured along market lines yet markedly unfriendly to consumers: ${ }^{31}$ a kind of openly clientilistic version of neoliberal reforms. Chilean water regulation exemplifies a specific ideal of transactional regulation in that the regulatory agency was established 9 years before full privatisation as a way of disciplining the (then) newly corporatised water company companies. The key issues that attract regulatory energy are tariff-setting, accounting processes for investment obligations, procurement processes, and mergers. Social issues are kept firmly separate from the regulatory agency, mainly consisting of a complex subsidy scheme administered by the municipalities.

A brief description of how tariffs are set is an emblematic instance of the texture of Chilean regulatory politics in water. The tariff system is based on hypothetical models of a perfectly efficient company, rather than on trying to cost in actually existing inefficiencies. Both the regulator and the company produce estimates based on their own models, using complex formulae that are laid down by the legislative framework, and public terms of reference for the models. 15 days of negotiation follow the production of estimates, and if no consensus can be reached, an expert panel of 3 makes the final decision. ${ }^{32}$

Interestingly, international arbitration is not a powerful feature of the regulatory space in Chilean water politics. One interpretation of this is that international investors respect the combination of the formal independence and substantive expertise of the regulator as sufficient to provide the political stability they need and seek. But an equally plausible reason for this comfort could be the political support enjoyed by international investors. The international private sector directly provides a majority of Chile's citizens with water services. The policy environment is sensitive to

31 In 2005 the World Economic Forum gave Chile first place for macroeconomic handling in a global survey, but only $53^{\text {rd }}$ place for consumer responsiveness: Eduardo Engel, 'Consumidores: tres tareas pendientes', La Tercera, 20 noviembre 2005.

32 One member is nominated by the relevant company, one by the regulator SISS and the third agreed upon by both. Often the third member (typically a PhD qualified economist) effectively decides the issue. The expert panel decisions have never been judicially reviewed, though heated technical debates regarding the parameters of the models have persisted and been clarified over time by legislative revision. 
perceptions of 'investment climate' held by these investors, and this undoubtedly shapes the regulatory dynamics. ${ }^{33}$ Moreover, the separation between economic and social issues mentioned above in the domestic context is mirrored in relation to transnational links. While dispute settlement does not strongly shape the Chilean regulatory environment in the water sector, Chile has extensive links to regional and global associations that set standards, such as AIDIS (InterAmerican Association of Engineers). Santiago also hosts the Latin American branches of both the UN Economic and Social Commission and of Consumers International, embedding it in international networks of actors who develop the social and consumer dimensions of water policy.

Overall, the day-to-day regulatory dynamics are dominated by a legalised power struggle between major interests, irritated at the margins by partypolitical dynamics which are often limited in their effectiveness due to the strong centralisation of executive power in Chilean constitutional structure. This creates less of a powerful basis for constructive conflict in regulatory politics in Chile than might initially seem to be the case. Routinised technocracy coexists with, but is relatively unresponsive to, a politicised debate portrayed in black-and-white terms. In this, there is little or no integration of professional expertise with modulated political input and feedback, and thus only very weak institutionalization of a regulatory culture that blends politics and expertise.

Arguably, an important 'missing link' is the absence of space for the routinised incorporation of 'everyday citizen' demands. In Bolivia, these were expressed through mass mobilisation and direct action. At best what exists in Chile is a highly individualised form of action within consumer law. In Argentina, as we shall see, lower levels of direct action coexist with administrative law-type procedures for vindicating the public interest. But in Chile there is a marked absence of such devices. ${ }^{34}$ Even though

33 Some interviewees made off-the-record comments regarding the subtle but powerful (investor-friendly) influence of the Ministry of Economics over SISS.

34 In 2004, consumer protection legislation was finally amended after a 6 year battle, to include a mild form of class action and some incentives to encourage collective consumer associations. However even this reform (which itself is much criticised: Eduardo Engel, 'Consumidores: tres tareas pendientes', La Tercera, 20 noviembre 2005, noting that only 3 collective actions were lodged in the first year since the law was passed) does not include public services within its remit. 
interviewees evoke an implicit social imaginary of a legalistic conception of the public interest underpinning regulatory dynamics, there is little institutional support for actually making this a reality. The legal device of recurso de proteccion (effectively the ability to obtain an injunction) does not facilitate collective consumer action: it is used mainly by the companies against the regulator (not least because it must be filed within 15 days of any harm occurring). In addition, it creates no stare decisis and relies on a dogmatic, slow and untransparent judicial process. There are no administrative courts where abusive and illegal action can be challenged by individuals. The most powerful oversight institution is the Controloria which is an auditor, and ensures the legality of executive decrees. The Controloria has facilitated an obsessive focus upon legality and administrative probity but in business-friendly ways rather than collective public interest. In short, the space for articulating claims of fairness, equity, or human rights is severely constricted.

Of course, there are still 'missing politics' that drive the regulatory dynamics away from the transactional model. It is not that lay-offs, tariff rises, or undue contractor influence do not exist in Chile. Rather, they seem not to spark the same kind of political mobilisation as they do in, for example, Argentina. One interviewee from the Central Labour Union in Chile said - with some regret - that 'in Argentina, when the lights go off, the people burn tires on the roadways and build barricades, while in Chile they simply go down to the supermarket and buy candles'. ${ }^{35}$ Direct action is remarkably muted, and public media coverage of water provision issues focuses overwhelmingly on making the country safe for foreign investors. There is certainly contestation. Some comes from individual legislators who take up the cause of constituency members. ${ }^{36}$ Citizen groups have also mobilised from time to time, albeit weakly. But the tight connections between local elites and the mainstream transactional consensus on water service provision means that managed liberalisation and transactional regulation dominate the Chilean case.

\footnotetext{
${ }^{35}$ Interview, Miguel Soto, Central Workers’ Union, January 2004.

${ }^{36}$ See motions filed by Chilean House of Representatives member Patricio Walker, of the Christian Democratic (DC), deputy Antonella Sciaraffia and senate candidate Fernando Flores: La Estrella de Iquique, reported. In Morrison and Foerster quarterly update.
} 


\section{WAter And Regulation in ARgentinA}

In the early 1990s, President Menem's sweeping neoliberal reforms to the Argentine economy set the stage for the entry of the international private sector into the water services sector. At the provincial level, these reforms were enacted more as a result of pressure from the federal government than from any locally relevant political dynamics, and this haunted the regulatory dynamics from the start. In Tucumán province, the troubled provincial state water company DIPOS had been governed by 15 different Directors between 1981 (when it was first transferred to provincial control from the federal government) and 1996. In March 1994, soon after the Tucumán government passed a legislative framework for privatization in March 1994 and by May 1995 had awarded a 30 year concession contract to Vivendi. ${ }^{37}$ At the same time, there were attempts to transform DIPOS into a regulator entitled ERSACT (Ente Regulador del Servicio de Agua y Cloadas de Tucuman). These began in late 1994 and were formalised by November 1995, in the process downsizing the 1,800 employees of DIPOS to 900. The transformation was formal and superficial, arguably one in name only, as employees were given little additional training or preparation for this entirely new role of regulating rather than operating. ${ }^{38}$

In this messy fashion, DIPOS became ERSACT, now ostensibly an independent regulator with the job of monitoring concessionaire providers of water. ERSACT suffered from being a provincial regulator established more or less through central fiat, as well as having no time to embed its new role before the international private sector began operating in the province. The outcome was that the regulator lacked substantial expertise, and played a populist role in the regulatory dynamics - one that was at times politically salient, though certainly not in the ideal-typical image of transactional regulation. The most interesting moment of ERSACT's political salience was when a leveraged coordination with the ombudsman

\footnotetext{
${ }^{37}$ Formally speaking the contract was with Vivendi's Argentine affiliate Aguas del Aconquija. The parent company was known as Compagnie Générale des Eaux (CGE) at the time of entering into the concession and more recently as Veolia, though still more popularly recognized as Vivendi, which will be the name used here. Although Aguas del Aconquija has a separate legal personality, it is controlled in substance by Vivendi.

${ }^{38}$ Interview with Daniel Arancibia, former President of ERSACT and Director of DIPOS, June 2004.
} 
occurred, as will be narrated below. While there were definite limits to the constructive nature of these regulatory politics, the episode certainly illustrates an interesting interaction of international, national and local pressures within one regulatory space, one which shows both the necessity of taking into account consumer group perspectives, and the significant limits on state responsiveness created by transnational pressures.

The concession contract contained detailed provisions about the service that Vivendi would provide, the tariffs it would charge, and the investments it would make. After the agreement was entered into, disputes arose between Vivendi and Tucumán over various issues including the method for measuring water consumption, the level of tariffs to customers, the timing and percentage of any increase in tariffs, the remedy for nonpayment of tariffs, Vivendi's right to pass-through to customers certain taxes, and the quality of the water delivered. The disputes took multiple forms at the domestic level but led ultimately to an arbitration claim lodged by Vivendi in the International Centre for the Settlement of Investment Disputes (ICSID). ${ }^{39}$

The possibility of international arbitration under ICSID shaped the larger political context. The federal government undertook a diplomatic mission to resolve the dispute informally, sending former President Menem of Argentina to France to negotiate there, pressuring provincial officials in Tucumán both publicly in the press and privately, ${ }^{40}$ and helping prepare a new agreement between Vivendi and Tucumán Province with a Working Group of the Provincial Attorney-General, a union representative and the CEO of Vivendi. ${ }^{41}$ This created significant pressure on the local dispute resolution dynamics, however subtly. A key focus of the broader regulatory dynamics was legislation that the legislature was trying to pass that would have mandated 'social tariffs' in an attempt to temper the

\footnotetext{
${ }^{39}$ Compañia de Aguas del Aconquija, S.A. \& Compagnie Générale des Eaux v. Argentine Republic, Award, ICSID Case No. ARB/97/3 (12 November 2000), 40 ILM 426, also available (with subseqent decisions on the same case) at http://www.worldbank.org/icsid/cases/awards.htm\#award15. The case was originally filed on February 19 1997, relying on a 1991 BIT between Argentina and France.

40 The Minister of Economy at the time, Fernandez, even threatened a federal-provincial lawsuit for the damage caused to Argentina's image in the eyes of foreign investors.

${ }^{41}$ Interview with Maria Pedicone de Valls, Provincial Attorney-General of Tucuman, August 2004.
} 
effects of tariff rises under the concession. A mix of party political moves, popular action on the streets, and small claims lawsuits kept pushing forward this focus. But ultimately it clashed with the transnational dimensions, as illustrated by the following story of the effect of an uneven background distribution of power.

In the summer of 1996, many thousands of users ceased paying their water bills in the wake of brown water and rising costs. The Tucumán Ombudsman advised consumers who did this to lodge an administrative dispute with the company alleging deficient rendering of services in respect of water quality and incorrectly calculated tariffs. ${ }^{42}$ Non-response to this dispute letter within 15 days bounced the dispute to the regulator, ERSACT, who issued two resolutions discounting consumers bills' in two respects. $^{43}$ Although only about $10 \%$ of payment boycotters filed the appropriate paperwork, this still amounted to some thousands of people. Vivendi did not challenge the decrees of the Ombudsman and regulator in local courts but continued to voice its disagreement even while invoicing customers in accordance with the decrees, and then immediately filing suit against the boycotters to recover the unpaid charges once they had rescinded the contract. Before the ICSID claim was filed, however, they preferred to continue with political negotiations.

The Ombudsman took two unprecedented steps in response to Vivendi's lawsuits against the boycotters, basing its strategy on the fact that the company was no longer the water provider by then. First, the Office tried to lodge a collective action lawsuit in the courts on behalf of the boycotters, but this was rejected in multiple consecutive fora by a series of different judges. Secondly, it offered individual legal assistance to consumers, having failed to secure such assistance from the local bar association. ${ }^{44}$ Now it is difficult to substantiate directly the shadow of the international power dynamics, not least because of the delicate political

42 This advice was supported by a series of resolutions issued by the Ombudsman's Office ( $n^{\circ} 66$ and $n^{\circ} 67$ of 1996) that highlight the details of why the invoicing was incorrect, drawing also on a public auditors' report to the same effect (Tucuman Audit Office Report 015, on file with author).

43 Resolution $n^{\circ} 212$ and $n^{\circ} 213$, discounting the bills first, by the amount of disputed taxes that Vivendi was passing through on the bill, and secondly by the amount paid for water during the periods that turbid, chocolate-coloured water was provided.

${ }^{44}$ Interview with Bossio, Ombudsman, August 2004.. 
nature of the conflict. ${ }^{45}$ But a somewhat extraordinary sequence of judicial evasions in response to the Ombudsman's claim resulted: in essence, 'they passed the ball from one to the other and nobody wanted to receive us'. ${ }^{46}$ The local bar association was similarly reluctant to become involved, and there were vociferous - albeit disputed ${ }^{47}$ - claims that the World Bank inserted a condition around that time on a large health and education loan that required conflicts with public service concessions to be eliminated or resolved. ERSACT was marginalised by the provincial government who intervened in a receiver-like process, appointing an alternative auditor to oversee the concession on the grounds that the company felt persecuted by ERSACT. ${ }^{48}$ Overall, there was a distinct sense that World Bank and ICSID processes constrained the domestic substantive and procedural possibilities, even if the precise mechanisms of intervention were disputed or indirect.

In terms of outcomes the legacy of this intersection of national and international developments was ambiguous. The Tucuman water services have been renationalised since 2004. Although the state company has struggled to improve water services, the forms of civil society involvement that were catalysed initially by private sector involvement have persisted into the renewed era of public service operation. Civil society continued to promote, after renationalisation, many legislative proposals, particularly relating to tariff structures, disconnection and the recovery of unpaid bills,

\footnotetext{
${ }^{45}$ This sensitivity is illustrated by the fact that a lawsuit filed by the Provincial AttorneyGeneral against Vivendi for breach of contract was later withdrawn when a change of government occurred and has never been re-filed, despite the promises of three consecutive Attorney-Generals to do so (Interviews with Ombudsman Bossio; Maria Pedicone de Valls Provincial Attorney-General; Jose Domieu and Jorge Abdala, both representing consumers' associations, August 2004).

${ }^{46}$ Interview with Maria Pedicone de Valls, Provincial Attorney-General of Tucuman, August 2004. The courts were willing to hear many individual claims against non-payers and issued sentences in relation to them, but the legislature intervened and passed a law suspending the enforcement of these sentences for six months. This law became another aspect of Vivendi's claim in the ICSID process

${ }^{47}$ Interviewees gave conflicting reports but a 13 August 1998 report in the local newspaper La Gaceta quoted Governor Bussi as saying that US\$55 million from the World Bank could not be disbursed until the federal government had taken over the concession, allowing Vivendi to leave.

${ }^{48}$ Interview with Daniel Arancibia, former President of ERSACT and Director of DIPOS, June 2004.
} 
both before and after the return of water services into public hands. In the short term, effects on participation opportunities were disappointing. No right to public hearings was obtained (although a precedent for this existed in electricity), and a promised consumer representative on ERSACT's Board of Directors never came to fruition.

But substantive gains were made, including legislative prohibition of water cut-offs to those using less than the basic minimum, and a 'dispute letter' which boycotting consumers successfully used to stave off legal action by Vivendi for non-payment, even after the Ombudsman's legal action stalled. ${ }^{49}$ And it is possible to argue that procedurally a kind of 'popcorn' incrementalism resulted: cumulatively, the unintended effects did open up more space for responding to consumer concerns. In particular, after a series of consumer group mobilisations in relation to different water services contracts across Argentina, several involving coalitions with international NGOs, a procedural victory of considerable significance has emerged: the acceptance by ICSID tribunals of amicus curiae briefs from civil society organizations, even in the face of objections from parties. ${ }^{50}$ Interestingly, what we see in these two kinds of gains is an uneasy truce between political regulation at the local level, and a more transactional model at the interface with transnational actors in arbitration fora. For even though the ICSID process amendment is a victory for participation, it is a form of participation that still sidesteps democractically elected governments, and does nothing to expand their policy space. Taken in conjunction with the recent award of US\$105 million by ICSID to Vivendi for compensation in the dispute, the opportunity to lodge a brief in ICSID hearings is at risk of being a marginal amendment to the overriding dominance of transactional regulation and the liberalised management model of global water welfarism.

${ }^{49}$ Interview with Jiminez Lascano, DUDAS consumers’ association, August 2004.

50 Aguas Argentinas S.A., Suez Sociedad General de Aguas de Barcelona S.A., Vivendi Universal S.A. c. República Argentina. Caso No ARB/03/19. See also more recently a similar order in a case involving the British water company Biwater in Tanzania: Biwater v Tanzania, Case No ARB/05/22, Procedural Order No.5. 


\section{CONCLUSION}

The case studies summarised in this article show a limited degree of institutional isomorphism (DiMaggio and Powell 1991) in the organisational choices of three Latin American states in the 1990s, each of whom formally established semi-independent regulatory agencies to monitor the delivery of water services. These emerged in a context shaped by the influence of conditional lending by international financial institutions and of a strong mainstream consensus on the desirability of transactional regulation. This consensus is embedded in a technocratic epistemic community whose members include national elites: in other words, it is national-international coalitions that support a liberalised management model for global water governance. No story of a 'transnational' transformation of the state is ever purely a story of external moulding.

Having said this, the apparent trajectory of imitative policy developments noted above is strongly tempered by the evidence presented in the case studies. This evidence supports two findings: first, national variation in the type and salience of regulatory dynamics persists despite the existence of transnationally rooted 'models'; and secondly, quasi-judicial institutions, particularly at the local or national level, are better able to respond to the legitimacy challenges raised by disaffected consumers and citizens than are regulatory agencies, especially agencies modelled on a transactional approach.

The first finding of national variation was summarised at the outset of this paper as divergence in the role played by the regulator in each case: transactional but marginalised in Bolivia, transactional and politically salient in Chile, political and erratically salient in Argentina. The difference can partly be accounted for by the larger political context in each country: Chile's stability and foreign-investment-friendly approach, provincial-federal conflict in Argentina's divided state, followed by an economic crisis, and Bolivia's political and social transformation towards the left. Whatever the causes of these larger contextual variables, ${ }^{51}$ they

${ }^{51}$ Or the causal effects: it is interesting to note that Evo Morales was involved in protests around the Cochabamba dispute and that one of the leading water activists in the conflict 
show that transformations of the state can constitute new currents in globalisation as well as flow from such currents. In particular, the local support in Bolivia of a political model of regulation may well have implications for future refinements of aan approach to global water governance based on participatory democracy. Bolivia's collaboration with Cuba, Nicaragua and Venezuela on the 'Bolivarian Alternative' supports such an approach for social services in general, including health, education and other essential infrastructure apart from water services.

While counterposing the Bolivian story with the Chilean story seems to contribute to a sense of polarised conflict between models of global water governance, however, certain aspects of Argentina's story point towards compromises that may blend the aspirations of both models, albeit in a manner that favours managed liberalisation even if it tips rather more towards management than liberalisation. For example, the capacity for NGOs and consumer groups to participate in international arbitration processes first recognised in one of the Argentinian disputes may create incentives for national and local governments to accord a more systematic place to consumer and citizen groups in national policymaking processes a trajectory encouraged by national-level litigation and political negotiations by those groups using devices like the recurso de proteccion, the ombudsman, or human rights provisions in the constitution.

This point leads to the second finding, which is related to the first. The case studies also reveal some important contributions that local or national institutions can make to temper polarised conflict in ways that build bridges between regulatory and citizen space. In no setting can a regulatory agency by itself generate such constructive politics. In the case of Bolivia, the agency is politically almost irrelevant to the generation of these politics; in the case of Argentina, the agency risks sliding into unproductive political clientilism yet has moments of productive synergy in its interactions with other institutions. In Chile, 'bureaucrats with an entrepreneurial kick' are constructive up to a point, but limited in the scope of their capacity to draw in the interests of ordinary citizens.

over water services in La Paz, Abel Mamani, became the first Water Minister for Bolivia under Morales. 
The lesson here is that even though independent regulatory agencies may routinise certain technical issues in water service delivery, they can rarely absorb conflict from direct protest. The technical and apolitical nature of regulatory discourse is often incommensurable with the value-driven nature of direct protest. However, quasi-judicial fora such as ombudsmen or small claims tribunals can link synergistically (and usually in unintended ways) with regulatory agencies in ways that at least routinise conflict, allowing winners and losers to emerge incrementally over time rather than intensifying polarisation in high-stakes rulemaking decisions. Thus quasi-judicial fora can, up to a point, absorb the 'missing politics' in regulatory dynamics in constructive ways, as was arguably the case in Argentina. In both Chile and Bolivia, the lack of such fora could be seen as undermining the overall legitimacy of the water services policy arena, but in Bolivia only, such discontent found its outlet in mass mobilisation and direct protest. This again links back to the macro-political context for each country, which favoured such action in Bolivia but not in Chile.

This finding is limited not only by contingent political contexts, but also by whether the quasi-judicial institution is locally embedded. The type of legitimacy deficit that bedevilled the water services investment contracts explored in this paper is one most intensely felt by local citizens, for whom an international investment arbitration forum compounds, rather than tempers, any felt injuries. Of course, transnational companies investing in longterm service contracts in developing countries may well feel the opposite: that local and national judicial and quasi-judicial fora lack the requisite legitimacy. In Argentina, the uneasy compromise of widening participation rights in international investment arbitration is the response. But it is not a response that alters the distributive politics at the root of the conflict, and thus there will always necessarily be a degree of polarisation around struggles over the appropriate way to govern access to water issues. $^{52}$ But this paper has shown that even seemingly domestic regulatory politics in relation to such struggles have a transnational dimension. Transnational, however, is precisely neither national nor international, external nor internal: it is, rather, a hybrid character embedded in coalitions of local, national and international actors. And

${ }^{52}$ Note recent move to Water Operator Partnerships (WOPS) and public-public ventures as an attempt to build bridges. It is too early to tell if it this will temper the conflicts over distribution. 
importantly, such coalitions are not restricted to those who support the managed liberalisation approach to social policy in the context of global governance. From the currents of conflict over access to water, flow approaches rooted in participatory democracy in all three case studies touched upon here, most strongly in Bolivia - and they do so in ways which constitute new forms of the transnational within the contours of their own states and beyond. 


\section{REFERENCES}

Chng, N., (2007), 'Civil Society and Water Services Provision in the Phillipines', Discussion Paper prepared for Wateraid, on file with author.

Conca, K. (2006), Governing Water: Contentious Transnational Politics and Global Institution Building (Cambridge, Mass: 2006)

Davis, M. (2006), Planet of Slums, London: Verso

Di Maggio and Powell (1991) The new institutionalism in organizational analysis (Chicago University Press)

Dublin Statement on Water and Sustainable Development, (1992), International Conference on Water and Environment, available at www.wmo.ch/web/homs/documents/english/icwedece.html.

Dubash, N. (2005), 'Regulation as an Arena for Social Policy', conference paper delivered for Arusha Conference, New Frontiers for Social Policy, December 2005, paper available at http://64.233.183.104/search?q=cache:ZJs6b1uL8L0J:siteresources.world bank.org/INTRANETSOCIALDEVELOPMENT/Resources/Dubash.rev.1 . df + dubash + electricity $\& h l=e n \& c t=c \ln k \& c d=8$

European Commission (2004), EU Water Facility: http://europa.eu.int/eurlex/en/com/cnc/2004/com2004_0043en01.pdf.

Foster, V (2001) 'Ten Years of Water Service Reform in Latin America: Towards an Anglo-French Model', Water Supply and Sanitation Sector Board Discussion Paper 3, available at www.worldbank.org/watsan.

Foweraker, J. 'Grassroots Movements, Political Activism and Social Development in Latin America: A Critical Comparison of Chile and Brazil', Journal of Latin American Studies 33(4) (2001), pp. 839-865 
Goldman, M., (2006) Imperial Nature: The World Bank and Struggles for Social Justice in the Age of Globalisation, (New Haven, Yale University Press)

Gott and Bartoli, Hugo Chavez: the Bolivarian Revolution in Venezuela (Verso 2005)

Jordana and Levi-Faur, (2005) 'The Diffusion of Regulatory Capitalism in Latin America: Sectoral and National Channels in the Making of a New Order', Annals of the American Academy of Political and Social Science 598: 102-124

Klerck, G. "Regulation Theory: Towards a synthesis in development studies”, Reconstruction Development and People (ed Jan Coetzee and Johann Graaff, International Thomson Publishing (Southern Africa) 1996.

LeClerc and Raes, Water: a World Financial Issue (PriceWaterhouseCoopers, Sustainable Development Series 2001)

Minogue and Carino (eds), 2006 Regulatory Governance in Developing Countries, Manchester: Edward Elgar Press.

Morgan, B. (2005), “Social Protest against Privatization of Water: Forging Cosmopolitan Citizenship?”, in Sustainable Justice: Reconciling International Economic, Environmental and Social Law, (eds Marie-Clair Cordonier Seggier and Justice Weeramantry), Martinus Nijhoff

Morgan, B. (2006a), Final Report to the ESRC on The Commodification of Water, Social Protest and Cosmopolitan Citizenship, March 2006, available at www.esrc.ac.uk.

Morgan, B. (2006b). 'Turning Off the Tap, Urban Water Service Delivery and the Social Construction of Global Administrative Law. European Journal of International Law, 17(1), 215-246.

Morgan, B. (2006c), “The North-South Politics of Necessity: Regulating for Basic Rights Between National and International Levels”, Special Issue of Journal of Consumer Policy on The Politics of Necessity (ed Morgan and Trentmann), vol. 29:4 
Morgan, B. (2007), "Global business, local constraints: the case of water in South Africa”, Chapter 10 of Making Global Self-Regulation Effective in Developing Countries, ed. Dana Brown and Ngaire Woods (Oxford: Oxford University Press)

Peck J and Tickell A (2002) Neoliberalizing space Antipode 34 (3): 380404

Silva, Tynan, and Yilmaz, 'Private Participation in the Water and Sewerage Sector - Recent Trends', 147 Public Policy for the Private Sector (1998) 1

Simpson, R. (2005). Universal access in the water and sanitation sector, draft paper produced for OECD-World Bank Fifth Services Expert Meeting, 3-4 February 2005, Paris, on file with author.

Terhorst, P., Public-Popular Organisations: the Case of Cochabamba, Bolivia, MSc thesis, Loughborough University, September 2003, on file with author

United Nations, Guiding Principles for Partnerships for Sustainable Development ('type 2 outcomes') to be Elaborated by Interested Parties in the Context of the World Summit on Sustainable Development (WSSD), 7 June 2002 (elaborating on GA Res. 56/226 (28 February 2002), available at

http://www.un.org/esa/sustdev/partnerships/guiding_principles7june2002. pdf

United Nations Taskforce on Water and Sanitation, Final Report January 2005, available at http://www.unmillenniumproject.org/reports/tf_watersanitation.htm. 